\title{
Morphological and photosynthetic adaptations of Tabebuia aurea seedlings in the nursery
}

\author{
Eduardo R. Gonçalves' ${ }^{1}$, Felipe C. Souza ${ }^{1}$, Luan N. dos Santos ${ }^{1}$, \\ José V. Silva ${ }^{2}$, Vilma M. Ferreira ${ }^{1} \&$ Lauricio Endres ${ }^{1}$
}

\begin{abstract}
Tabebuia aurea (Benth. \& Hook. f. ex S. Moore) (Bignoniaceae) is a boreal species common in Brazil. It is used for ornamental parks and along sidewalks. Its timber is also used for furniture. The objective of this study was to evaluate the effect of nursery shading on the growth and photosynthesis of $T$. aurea and their photosynthetic adaptation after being transferred to direct sunlight. The $T$. aurea seedlings were grown under $0,50,70$ or $95 \%$ shade. The photosynthetic active radiation and leaf gas exchange were measured over two distinct periods: 51 (young seedlings) and 70 days after having been sown under each shade treatment. Immediately after the measurements were taken, the seedlings were transferred into full sunlight and the measurements were repeated two times after $15 \mathrm{~min}$ and 3 days under ambient sunlight. T. aurea seedlings showed satisfactory growth up to $50 \%$ shade in the nursery, which could be verified both by growth measurement and by total biomass accumulation. Shading greater than $70 \%$ reduced the number of leaves, the leaf area and the stem diameter in relation to plants exposed to full sunlight. The results suggest that $T$. aurea seedlings should be grown under full sunlight or under shading up to $50 \%$ to maximize their growth in the nursery and to minimize stress when transferring the seedlings to their final planting sites.
\end{abstract}

Key words: Bignoniaceae, nursery, Atlantic Forest, leaf gas exchange

\section{Adaptações morfológica e fotossintética de plântulas de Tabebuia aurea no viveiro}

RESUMO

Tabebuia aurea (Benth. \& Hook. f. ex S. Moore) (Bignoniaceae) é uma espécie arbórea comum no Brasil, utilizada para fins ornamentais de calçadas e parques cuja madeira é usada para fabricação de móveis. O objetivo deste estudo foi avaliar o efeito do sombreamento no crescimento e na fotossíntese de mudas de $T$. aurea e sua adaptação fotossintética após transferência ao sol pleno. As plântulas de T. aurea foram cultivadas sob $0,50,70$ e $95 \%$ de sombreamento. Sob cada condição de sombreamento foram avaliadas a radiação fotossinteticamente ativa e as trocas gasosas das folhas aos 51 (plântulas jovens) e após 70 dias após a semeadura das sementes sem o uso de luz artificial; logo em seguida as plântulas foram transferidas para o sol pleno e nova medidas foram feitas após 15 min e 3 dias da transferência para a nova condição. As plântulas de T. aurea apresentaram crescimento satisfatório até o nível de $50 \%$ de sombreamento no viveiro que pôde ser verificado tanto pelo crescimento como pelo acúmulo de biomassa total. O sombreamento acima de $70 \%$ reduziu o número de folhas, área foliar e o diâmetro do coleto em relação às plantas expostas ao pleno sol. Os resultados sugerem que plântulas de $T$. aurea devem ser cultivadas em sol pleno ou com sombreamento de até $50 \%$ para maximizar o crescimento no viveiro e minimizar o estresse de transferência das mudas para o local de plantio definitivo.

Palavras-chave: Bignoniaceae, produção de mudas, Floresta Atlântica, plântulas, trocas gasosas foliar 


\section{INTRODUCTION}

Extensive deforestation has changed the land cover of the region that was once the heart of Brazil's Atlantic rainforest. The forest once stretched over 1 million square kilometers along Brazil's coastal region with extensions inland. Today, only $7 \%$ of that original forest remains (Wuethrich, 2007). Despite continued forest conversion and degradation, forest cover is increasing in countries across the globe. New forests are regrowing on former agricultural land, and forest plantations are being established for commercial and restoration purposes (Chazdon, 2008).

In a human-impacted landscape, the new forest will not match the original forest in terms of species composition. The re-introduction of the original species is essential to increase biodiversity. For example, the dominance of a single $\mathrm{N}_{2}-$ fixing tree species in a legume mixture caused faster biomass accumulation and higher $\mathrm{N}$ concentrations in the biomass and litter than a diverse mixture with a low density of $\mathrm{N}_{2}$ fixers (Siddique et al., 2008).

Establishing a self-sustainable reforested area with adequate biodiversity is the main goal of any reforestation program. Thus, knowledge of the ecophysiological behavior of the species to be used is crucial (Endres et al., 2010; Souza et al., 2010). In agroforestry, environmental limitations to plant growth are fairly common (Vilela \& Ravetta, 2000). Light, water, temperature and soil conditions typically influence plant growth and development (Felfili et al., 1999). Among these factors, low light levels can limit photosynthesis, resulting in reduced growth, while excessive light can damage the photosynthetic apparatus. Light can also influence other physiological processes, both quantitatively and qualitatively. For this reason, environments that are either shaded or that receive full sunlight can inhibit the photosynthetic process simply because there is too little or too much light (Zhang et al., 2003).

Measurements of photosynthetic and morphological responses to light may reveal the tolerance of species to light intensity and have been useful in agriculture, ecology, forestry and horticulture (Aleric \& Kirkman, 2005). Efficient photosynthetic activity is necessary for the high production of plant biomass. Nevertheless, abiotic and physiologically controlled factors (e.g., stomatal conductance and transpiration) can strongly influence photosynthetic activity (Gonçalves et al., 2005).

The species Tabebuia aurea (Benth. \& Hook. f. ex S. Moore) is native to Brazil, occurring in very humid regions (the Amazon, Pantanal and Atlantic Forest) as well as more arid regions (the caatinga and cerrado). Its timber is used for furniture, and the tree is also used as an ornamental species, in reforestation, in parks and along sidewalks (Lorenzi, 2002).

Scientific articles related to shading typically consist of experimental studies on the growth of seedlings under different light levels that aim to understand the behavior of plant species during the process of reforestation and the requirements for the growth of seedlings in nurseries. Several native species have been used in shading studies, including many tropical tree species (Fonseca et al., 2002; Aguiar et al., 2005; Lima Jr. et al., 2006). However, little is known about the photosynthetic acclimation of seedlings grown in nurseries to reforestation areas (Aleric \& Kirkman, 2005; Lima Jr. et al., 2005; Endres et al., 2010), and a significant photosynthetic depression can occur when seedlings acclimated to shade are suddenly exposed to full sunlight (Zhang et al., 2003).

The objective of this study was to evaluate the effect of nursery shading on the growth and photosynthesis of $T$. aurea seedlings (Benth. \& Hook. f. ex S. Moore) (Bignoniaceae) and their photosynthetic adaptation after being transferred into direct sunlight. In this paper, it was describe how different light intensities can alter seedling morphology and leaf gas exchange. The photosynthetic adaptation of seedlings exposed to full sunlight after being acclimated to shading is also described.

\section{Material And Methods}

The experiment was conducted at Maceio, Alagoas State, Brazil, at the geographic coordinates $07^{\circ} 35^{\prime} 43.8^{\prime \prime} \mathrm{S}$ and $45^{\circ}$ 46 '0 8" W, at $60 \mathrm{~m}$ above sea level.

Seeds were collected from Craibeira trees [T. aurea (Benth. \& Hook. f. ex S. Moore)] and immediately sown in a $1 \mathrm{x} 3 \mathrm{~m}$ bed under a Syzygium cumini tree. The Environment Institute of Alagoas (IMA) identified the botanical material, and one exsiccate of the trees from which the seeds were collected was deposited in the institute herbarium, under the number MAC21433.

Seedlings $(5 \mathrm{~cm}$ in height) were transferred to individual polyethylene bags with $3.5 \mathrm{dm}^{3}$ of soil, which was composed of $60 \%$, loamy soil, $20 \%$ sand and $20 \%$ cattle manure. After the soil was prepared, no further fertilization was conducted until the end of the experiment.

Ten days after being sown, 30 seedlings (replicates) were transferred to each shade treatment, as follows: no shading, with seedlings exposed to direct sunlight; seedlings arranged under a black polypropylene net with $50 \%$ shading; seedlings arranged under a black polypropylene net with $70 \%$ shading; seedlings arranged under a Syzygium cumini canopy with $\sim 95 \%$ shading.

The photosynthetic active radiation (PAR) under each shade net was measured over two distinct periods with a PAR sensor (LCi, ADC, Hoddesdon, UK) between 10:00 a.m. and 12:00 a.m. (Figure 1).

The black polypropylene nets do not always supply the ideal shading levels indicated by the manufacturer (Figure 1). The $70 \%$ shade net reduced the PAR by $85 \%$, while the $50 \%$ shade net reduced the luminosity by $61 \%$. The values, which were measured between 10:00 a.m. and 12:00 p.m., may change during the day or over the course of the year due to the sun angle. The $95 \%$ shade treatment was conducted under a Syzygium cumini canopy, which may have increased the red light in relation to net shading. However, it should be noted that the light treatments were very different, making the light quality effects negligible.

The seedlings were irrigated three times a day for the first 20 days after being sown and twice a day after that until the end of the experiment.

The seedling height and leaf number per shoot were measured every 10 days from the $11^{\text {th }}$ until the $70^{\text {th }}$ day after sowing. 

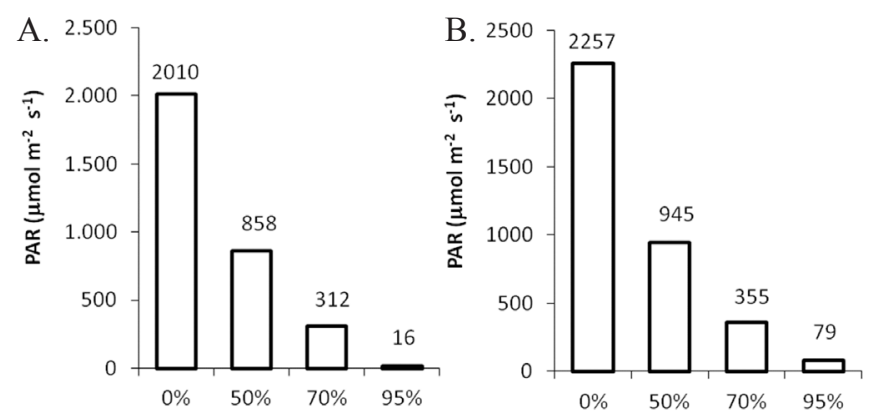

C.
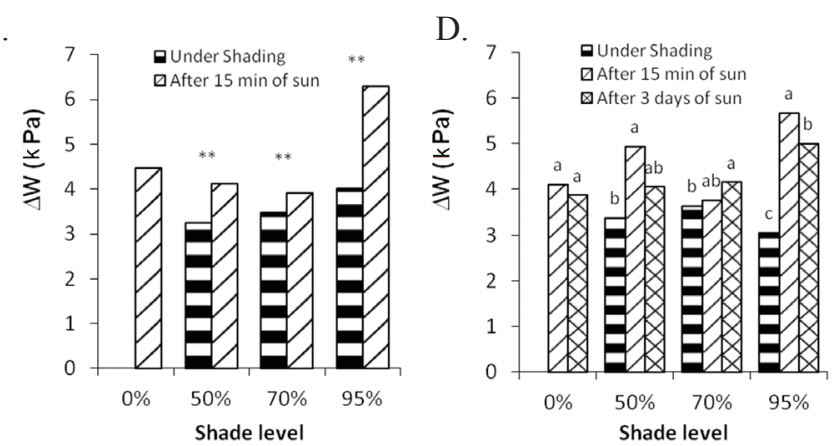

Columns in the same shading level are significantly different at $\mathrm{P}<0.05\left(^{*}\right)$ and at $\mathrm{P}<0.01$ $\left({ }^{* *}\right)$ by t-test $(\mathrm{N}=8)$ and columns in the same shading level followed by different letters indicate significant differences $(\mathrm{N}=8$, Tukey test, $\mathrm{P}<0.05)$

Figure 1. Photosynthetic active radiation (PAR) under different shade net measured from 10:00 to $12: 00$ at geographic coordinates $07^{\circ} 35^{\prime} 43.8^{\prime \prime} ' \mathrm{~S}$ and $45^{\circ} 46^{\prime} 08^{\prime \prime}$ 'W on 02/03/2005 (A) and 19/03/2005 (B) and leaf-to-air vapor pressure deficit $(\Delta \mathrm{w})$ on 02/03/2005 (C) and 19/03/2005 (D) of the Tabebuia aurea grown under different shading levels and then the seedlings were transferred to full sunlight, measured $15 \mathrm{~min}$ later and then only measured again 3 days later

The leaf gas exchange was measured for eight seedlings (replicates) under each shading treatment (without artificial light) at 51 (young seedlings) and 70 days after sowing. Then, the seedlings were transferred to full sunlight for $15 \mathrm{~min}$, and the measurements were repeated under ambient sunlight (over 2,000 $\mu \mathrm{mol} \mathrm{m}^{-2} \mathrm{~s}^{-1}$ ). After three days under ambient light, the same leaves were measured again to quantify their photosynthetic acclimation to the new light regime, simulating the transfer of seedlings from the nursery to the field. This three-day acclimation to full sunlight was not done in the young seedlings to avoid damaging them.

Leaf gas exchange was measured by an infrared gas analyzer (IRGA) (LCi, ADC, Hoddesdon, UK) on the first expanded leaf after two minutes of equipment acclimation on the leaf. The following parameters were obtained: photosynthesis (A), transpiration (E), stomatal conductance (gs), internal and external leaf $\mathrm{CO}_{2}$ concentration ratio $(\mathrm{Ci} / \mathrm{Ca})$, instantaneous water use efficiency $(\mathrm{A} / \mathrm{E})$, leaf-to-leaf chamber temperature difference (Tf-Tc) and instantaneous carboxylation efficiency $(\mathrm{A} / \mathrm{Ci})$. The leaf-to-air vapor pressure deficit $(\Delta \mathrm{w})$ was calculated from the air temperature, air humidity and leaf temperature, considering the leaf mesophyll air space as saturated with water vapor. The IRGA measurements were taken between 10:00 a.m. and 12:00 p.m. under the light conditions described above (Figs. 1A and B). The values of leaf-to-air vapor pressure deficit ranged from 3.1 to $7.1 \mathrm{kPa}$ (Figs $1 \mathrm{C}$ and D), the leaf chamber temperature ranged from 34 to $42{ }^{\circ} \mathrm{C}$ and the ambient $\mathrm{CO}_{2}$ concentration ranged from 365 to $378 \mathrm{vpm}$.

Seventy days after sowing, the seedlings were collected, and their collar diameters were measured. The root, leaf and stem were separated, and their dry masses were determined after drying them in a forced-air circulation oven at approximately $70^{\circ} \mathrm{C}$ until constant weights were achieved. Before drying, the leaves were scanned, and the leaf area was estimated by the Quant v.1.0.1 software. From the dry mass and leaf area data for each seedling, the following parameters were obtained:

$$
\begin{gathered}
\text { Stem ratio }(\%)=\frac{\text { Stem dry mass }}{\text { Seedling total mass }} \times 100 \\
\text { Leaf ratio }(\%)=\frac{\text { Leaves dry mass }}{\text { Seedling total mass }} \times 100 \\
\text { Root ratio }(\%)=\frac{\text { Root dry mass }}{\text { Seedling total mass }} \times 100 \\
\text { Leaf area ratio }(\%)=\frac{\text { Leaves area }}{\text { Seedling total mass }}\left(\mathrm{mm}^{2} \mathrm{~g}^{-1}\right) \\
\text { Specific leaf area }(\%)=\frac{\text { Leaf area }}{\text { Leaf dry mass }}\left(\mathrm{mm}^{2} \mathrm{~g}^{-1}\right)
\end{gathered}
$$

The results were statistically analysed as a randomized design with 30 replications per treatment for morphological characteristics and with eight replications per treatment for the leaf gas exchange data. The data were submitted to analysis of variance using the F-test, and the means were compared by Tukey test at 0,05 and t-test. No data transformation was necessary. Pearson's coefficient of correlation ( $r$ ) was used to quantify the relationship between physiological parameters. All statistical analysis were performed using Statistica 6.0 from StatSoft, Inc.

\section{RESUlts AND Discussion}

Shading strongly influenced the gas exchange of the plants, as shown by the positive correlations between PAR and stomatal conductance, PAR and transpiration, PAR and photosynthesis as well as PAR and instantaneous water use efficiency (Tab. 1). These correlations disappeared when the plants were placed under direct sunlight. The plants exposed to direct sunlight for three days showed negative correlations between PAR and photosynthesis as well as between PAR and instantaneous water use efficiency, possibly indicating photoinhibition and a subsequent decrease in $\mathrm{CO}_{2}$ assimilation because the plants were not acclimated to high irradiance conditions. Similar results were observed in Lycoris radiata var. Radiata plants grown under 0 to $1,500 \mu \mathrm{mol} \mathrm{m}^{-2} \mathrm{~s}^{-1}$ (Zhou et al., 2010).

Shading of up to $70 \%$ did not affect the height of T. aurea plants. However, under $95 \%$ shade, the plant height was 
Table 1. Pearson's correlation coefficient between physiological parameters in Tabebuia aurea seedlings grown under shade and after transferring them to 15 min and 3 days in sunlight

\begin{tabular}{|c|c|c|c|c|c|c|c|}
\hline & $E$ & $g_{s}$ & A & $\mathrm{Ci} / \mathrm{Ca}$ & $A / E$ & $T_{\mathbf{f}}-T_{G}$ & $\Delta \mathrm{W}$ \\
\hline \multicolumn{8}{|c|}{ A) Grown under shade } \\
\hline PAR & $0.67^{* \star}$ & $0.80^{\star \star}$ & $0.93^{\star \star}$ & $-0.90 * \star$ & $0.93^{\star \star}$ & $0.59 \star \star$ & $0.23^{\text {ns }}$ \\
\hline $\mathrm{E}$ & & $0.91^{\star \star}$ & $0.82^{\star \star}$ & $-0.79 * \star$ & $0.75^{\star \star}$ & $-0.10^{\text {ns }}$ & $0.76^{\star \star}$ \\
\hline$g_{s}$ & & & $0.90 * *$ & $0.81^{* *}$ & $0.83^{* *}$ & $0.08^{\text {ns }}$ & $0.44^{*}$ \\
\hline$A$ & & & & $-0.97^{\star *}$ & $0.98^{\star \star}$ & $0.40^{\text {ns }}$ & $0.40^{\text {ns }}$ \\
\hline $\mathrm{Ci} / \mathrm{Ca}$ & & & & & $-0.99 * \star$ & $-0.42^{*}$ & $-0.46^{\star}$ \\
\hline$A / E$ & & & & & & $0.47 *$ & $0.34^{\mathrm{ns}}$ \\
\hline$T_{t}-T_{c}$ & & & & & & & $-0.31^{\mathrm{ns}}$ \\
\hline \multicolumn{8}{|c|}{ B ) Grown under sun } \\
\hline PAR & $-0.04^{\mathrm{ns}}$ & $0.02^{\text {ns }}$ & $-0.06^{n s}$ & $-0.10^{\text {ns }}$ & $-0.03^{\text {ns }}$ & $0.72^{\star \star}$ & $0.14^{\mathrm{ns}}$ \\
\hline $\mathrm{E}$ & & $0.82^{\star \star}$ & $0.67^{\star \star}$ & $0.87^{\star \star}$ & $-0.18^{\text {ns }}$ & $-0.69 * *$ & $-0.03^{\text {ns }}$ \\
\hline$g_{s}$ & & & $0.92^{* *}$ & $0.78 * \star$ & $0.32^{\text {ns }}$ & $-0.46^{\text {ns }}$ & $-0.53^{\star}$ \\
\hline A & & & & $0.52^{\star}$ & $0.60^{\star}$ & $-0.41^{\text {ns }}$ & $-0.72^{\star \star}$ \\
\hline $\mathrm{Ci} / \mathrm{Ca}$ & & & & & $-0.27^{\mathrm{ns}}$ & $-0.61^{*}$ & $-0.05^{n s}$ \\
\hline$A / E$ & & & & & & $0.20^{\text {ns }}$ & $-0.92^{\star *}$ \\
\hline$T_{T^{-}}-T_{c}$ & & & & & & & $-0.02^{\mathrm{ns}}$ \\
\hline \multicolumn{8}{|c|}{ C) Shade grown and exposure to $15 \mathrm{~min}$ in sun } \\
\hline PAR & $0.36^{\text {ns }}$ & $0.36^{\text {ns }}$ & $0.23^{\text {ns }}$ & $0.11^{\text {ns }}$ & $0.00^{\mathrm{ns}}$ & $-0.31^{\mathrm{ns}}$ & $-0.09^{n s}$ \\
\hline E & & $0.91^{\star *}$ & 0.75 & $-0.04^{n s}$ & $0.03^{\text {ns }}$ & $-0.99 * *$ & $0.08^{\text {ns }}$ \\
\hline$g_{s}$ & & & $0.88 * *$ & $-0.19^{\text {ns }}$ & $0.34^{\mathrm{ns}}$ & -0.87 ** & $-0.26^{n s}$ \\
\hline A & & & & $-0.61^{\star \star}$ & $0.68^{\star *}$ & $-0.69 * *$ & $-0.55^{\star *}$ \\
\hline $\mathrm{Ci} / \mathrm{Ca}$ & & & & & $-0.84^{* *}$ & $-0.01^{\mathrm{ns}}$ & $0.65^{\star *}$ \\
\hline$A / E$ & & & & & & $0.05^{\text {ns }}$ & $-0.95^{\star \star}$ \\
\hline $\mathrm{T}_{\mathrm{f}}-\mathrm{T}_{\mathrm{C}}$ & & & & & & & $-0.17^{\mathrm{ns}}$ \\
\hline \multicolumn{8}{|c|}{ D) Shade grown and exposure to 3 days in sun } \\
\hline PAR & $-0.38^{\text {ns }}$ & $-0.39^{\text {ns }}$ & $-0.46^{*}$ & $0.49^{\star}$ & $-0.53^{\star *}$ & $0.09^{\text {ns }}$ & $0.64^{\star *}$ \\
\hline E & & $0.98^{\star \star}$ & $0.92^{\star \star}$ & $-0.55^{\star \star}$ & $0.74^{\star \star}$ & $-0.34^{\mathrm{ns}}$ & $-0.83^{\star \star}$ \\
\hline$g_{s}$ & & & $0.93^{* *}$ & -0.56 ** & $0.75^{\star *}$ & $-0.42^{*}$ & $-0.84 * *$ \\
\hline A & & & & -0.81 ** & $0.93^{* *}$ & $-0.27^{\mathrm{ns}}$ & $-0.89 * *$ \\
\hline $\mathrm{Ci} / \mathrm{Ca}$ & & & & & -0.96 ** & $-0.06^{\mathrm{ns}}$ & 0.70 ** \\
\hline$A / E$ & & & & & & $-0.18^{\mathrm{ns}}$ & $-0.85^{* *}$ \\
\hline$\underline{T_{f}-T_{c}}$ & & & & & & & $0.31^{\mathrm{ns}}$ \\
\hline
\end{tabular}

Abreviations: photosynthetic active light (PAR), transpiration (E), stomatal conductance (gs), photosynthesis $(A)$, leaf internal and external $\mathrm{CO}_{2}$ concentration ratio $(\mathrm{Ci} / \mathrm{Ca})$, instantaneous water use efficiency $(A / E)$, leaf-to-leaf chamber temperature difference $\left(T_{-}-T_{c}\right)$, leaf-to-air vapour pressure deficit $(\Delta \mathrm{W})$. ${ }^{*}, \mathrm{P}<0.05 ;{ }^{* *}, \mathrm{P}<0.01$; and ${ }^{\text {ns }}$ not significant $\mathrm{P}<0.05$

reduced by approximately $40 \%$ (Figure $2 \mathrm{~A}$ ). The stem heights of Tabebuia chrysotricha and Tabebuia avellanedae Lorentz Griseb grown under different light intensities have also been shown to be reduced 130 and 90 days after planting, respectively, especially in plants grown in 95\% shade (Endres et al., 2010). Furthermore, Almeida et al. (2005) found a significant height reduction of $31 \%$ in Jacaranda puberula Cham at 120 days after planting when grown under $50 \%$ shade. However, no reductions were observed in the height of Caesalpinia echinata Lam. (Aguiar et al., 2005) grown under up to $80 \%$ shade, in Psidium cattleianum grown under up to $70 \%$ shade (Ortega et al., 2006) or in Bombacopsis glabra (Pasq.) A. Robyns grown under up to 50\% shade (Scalon et al., 2003) at 720, 120 and 124 days after planting, respectively. However, some plants grew taller under shade conditions, such as Hymenaea parvifolia (Silva et al., 2007), Croton urucurana Baill. (Alvarenga et al., 2003), Simarouba amara Aubl. (Azevedo et al., 2010) and Trema micrantha (L.) Blume (Fonseca et al., 2002).

Shading also negatively affected the number of leaves of $T$. aurea, especially at $95 \%$ shade, with a reduction of $44 \%$ (Figure 2B). Despite not affecting plant height (Figure 1A), $70 \%$ shade reduced the number of leaves compared to plants
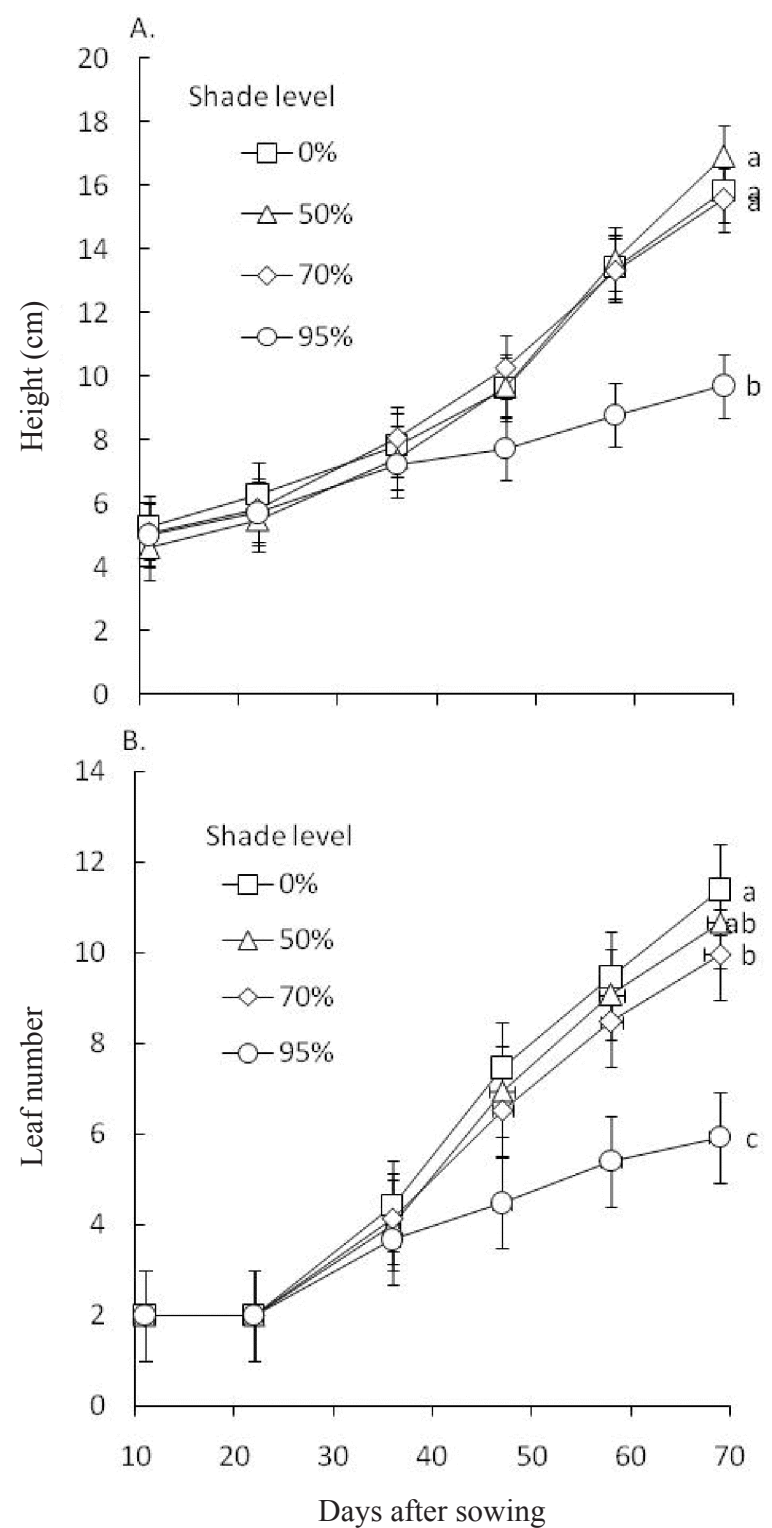

The data is means with standard error bars $(\mathrm{N}=30)$. Values taken from 70 days after being sown followed by different letters indicate significant differences (Tukey test, $\mathrm{P}<0.05$ )

Figure 2. Height $(A)$ and leaf number $(B)$ of the Tabebuia aurea seedling's grown under different shading net

exposed to full sunlight (Figure 2B). Changes in the number of leaves were not observed in Hymenaea parvifolia (Silva et al., 2007) under up to $70 \%$ shade at 105 days after planting, Simarouba amara Aubl under up to $70 \%$ shade at 182 days after germination (Azevedo et al., 2010) or Caesalpinia echinata Lam under up to $80 \%$ shade analysed at 12,18 and 24 months after germination (Aguiar et al., 2005). Moreover, Fonseca et al. (2002) found reductions in the number of leaves in Trema micrantha (L.) Blume grown under $48 \%$ shade at 120 days after germination, while Endres et al. (2010) reported a significant increase in the number of leaves in Tabebuia chrysotricha, especially those grown under $70 \%$ shade at 130 days after planting.

Shading caused an increase in the biomass allocation to the shoot at the expense of the root system in T. aurea (Figure 3). The allocation of dry mass in the shoots ranged from 76 (full sunlight) to $87 \%$ ( $95 \%$ shade) (Figure $3 \mathrm{~A}$ and C). Endres et 
al. (2010) reported similar results in Tabebuia chrysotricha. The higher biomass allocation to the shoot was primarily due to the higher allocation of biomass in the leaves, ranging from $48 \%$ (full sunlight) to $55 \%$ (95\% shade) (Figure 3C), and no significant change was observed in the allocation of biomass to the stem (Figure 3A). Ortega et al. (2006) showed reductions greater than $60 \%$ in the dry mass of shoots in Psidium cattleianum seedlings, especially when grown at $70 \%$ shade at 120 days after transplanting.
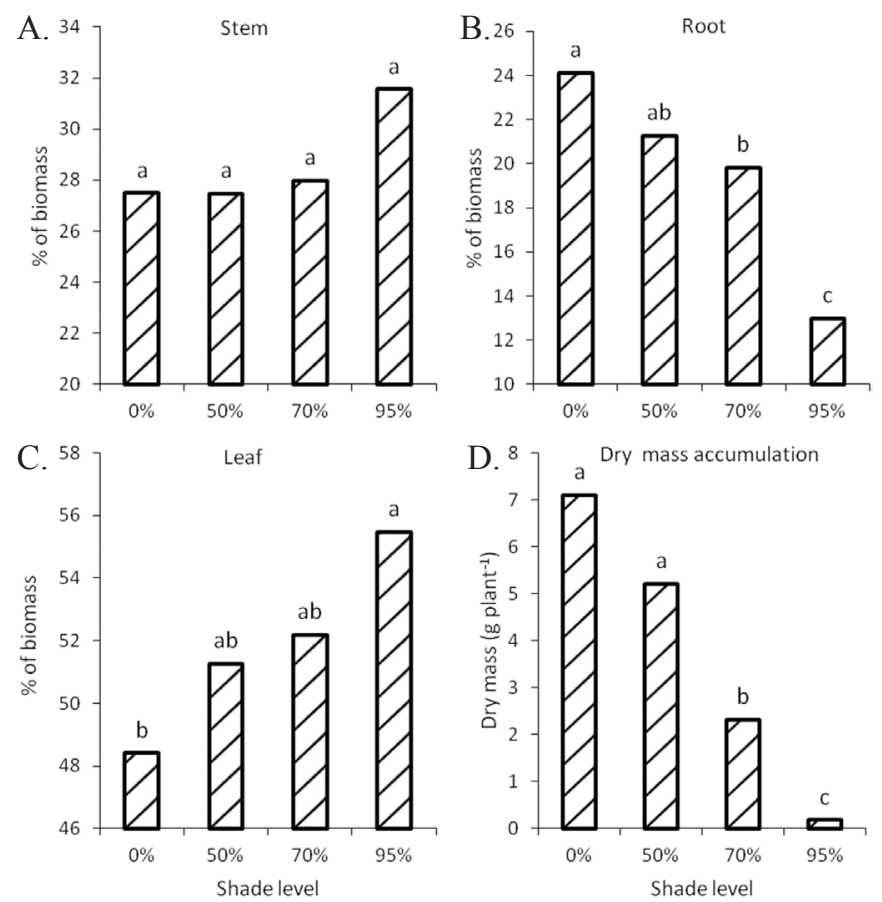

Columns followed by different letters indicate significant differences $(N=30$, Tukey test, $P$ $<0.05)$

Figure 3. Proportional allocation of dry mass to stem (A), root (B) and leaf (C) and total biomass accumulation (D) of the Tabebuia aurea grown under different shading level

The dry mass allocation to the root system of $T$. aurea ranged from $13 \%$ (under $95 \%$ shade) to $24 \%$ (under full sunlight, Figure 3B). Silva et al. (2007) and Endres et al. (2010) observed reductions in the dry mass of the root systems of Hymenaea parvifolia and Tabebuia chrysotricha plants, respectively, under $70 \%$ shade, while Dantas et al. (2009) observed no significant differences in the dry masses of roots in seedlings of Caesalpinia pyramidalis Tul. grown under $75 \%$ shade at 100 days after sowing. The lower allocation of biomass to the roots as a result of shading, as occurred in this study, may reduce water and nutrient absorption, causing plants to loose their capacity to support higher rates of photosynthesis and transpiration in environments with more light (Carvalho et al., 2006). Furthermore, the dry matter allocation is an important process considering that biomass allocation plasticity to different organs may be crucial to the establishment of a seedling in a new environmental condition, for example, shading caused by other trees (Endres et al., 2010).

Total dry matter accumulation decreased dramatically under $70 \%$ shade (Figure 3D). Plants grown under $95 \%$ shade showed a total dry mass accumulation equivalent to $2.53 \%$ of the biomass of plants exposed to ambient sunlight. Similar results were found in seedlings of Tabebuia chrysotrich a grown under $70 \%$ shade at 130 days after planting (Endres et al., 2010), in Psidium cattleianum grown under $30 \%$ shade at 120 days after planting (Ortega et al., 2006), in Trema micrantha (L.) Blume grown under $48 \%$ shade at 120 days after germination (Fonseca et al., 2002) and in Simarouba amara Aubl. (Simaroubaceae) grown under $70 \%$ shade at 182 days after germination (Azevedo et al., 2010).

The leaf area of $T$. aurea decreased dramatically under $70 \%$ and higher levels of shade (Figure 4A). Similar results were observed in Jacaranda puberula Cham. (Almeida et al., 2005) and in $T$. chrysotricha (Endres et al., 2010) under more than $70 \%$ shade. Ortega et al. (2006), however, observed no change in leaf area in Psidium cattleianum seedlings grown under 30 to $70 \%$ shade at 120 days after transplanting. The same finding was reported by Dantas et al. (2009) in Caesalpinia pyramidalis Tul. subjected to $75 \%$ shade. However, increased leaf area due to shading was observed in Hymenaea parvifolia grown under $50 \%$ shade (Silva et al., 2007) as well as Croton urucurana Baill. (Alvarenga et al., 2003) and Simarouba amara Aubl. (Azevedo et al., 2010) both grown under 70\% shade.

The increase in leaf area may be one of the mechanisms used by plants to increase the photosynthetic surface, ensuring more efficient photosynthetic performance under low light intensity and thus compensating for the low rate of net $\mathrm{CO}_{2}$ assimilation per unit of leaf area, a characteristic of shaded leaves (Gordon, 1969). However, in plants subjected to environments with more light, the leaf area is decreased, which is beneficial to the plant given that less leaf material is exposed to potential damages
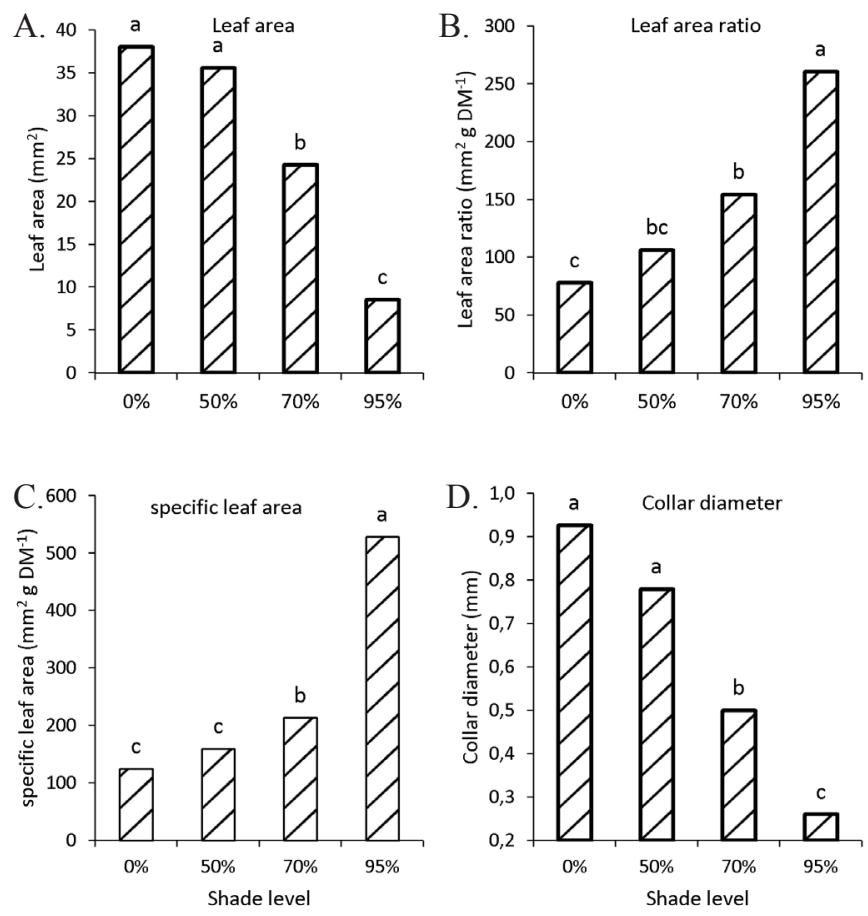

Columns followed by different letters indicate significant differences ( $N=30$, Tukey test, $P$ $<0.05)$

Figure 4. The mean leaf area (A), leaf area ratio (B), specific leaf area $(C)$ and collar diameter (D) of the Tabebuia aurea grown under different shading levels 
caused by excess light (Claussen, 1996). Nevertheless, in this study, it was observed that the greater the shade, the smaller the leaf area, indicating that other factors may have hindered the development of the plant.

The ratio of $T$. aurea leaf area, i.e., the usable area of the plant for photosynthesis (Benincasa 2003), showed significant increases at $70 \%$ and greater levels of shade (Figure 4B). Similar results were observed by Silva et al. (2007) in Hymenaea parvifolia, Dantas et al. (2009) in Caesalpinia pyramidalis Tul. and Endres et al. (2010) in T. chrysotricha. Plants grown under $95 \%$ shade (under the Syzygium cumini canopy) showed a dramatic increase in leaf area ratio (Figure 3B) and specific leaf area (Figure 3C). Part of this phenology could be attributed to changes in the light spectrum caused by the tree shading in this treatment and not just the lower light level (Endres et al., 2010).

The specific leaf area of $T$. aurea increased significantly under $70 \%$ and higher levels of shade, reaching values 4.2 times greater (under $95 \%$ shade) than those observed in plants grown under direct sunlight. Similar results were found in T. chrysotricha (Endres et al., 2010) when it was grown under more than $70 \%$ shade. However, Dantas et al. (2009) found no significant differences in the specific leaf area of Caesalpinia pyramidalis Tul grown under up to $75 \%$ shade.

Collar diameter showed significant reductions from $70 \%$ shading, becoming more evident at $95 \%$ shading. This reduction was superior to $70 \%$ compared to plants grown in full sunlight. Almeida et al. (2005) also found a reduction in collar diameter in Jacaranda puberula, as did Fonseca et al. (2002) in Trema micrantha (L.) Blume plants, Aguiar et al. (2005) in Caesalpinia echinata Lam. seedlings and Endres et al. (2010) in $T$. chrysotricha seedlings subjected to different levels of shading. In contrast, Ortega et al. (2006), Scalon et al. (2003) and Silva et al. (2007) observed no significant difference in collar diameter in seedlings of Psidium cattleianum, Bombacopsis glabra (Pasq.) A. Robyns and Hymenaea parvifolia, respectively, under shade. According to Kozlowski (1962), the increased shade decreases photosynthesis and, consequently, the amount of photoassimilates and growth regulators, causing a reduction in stem diameter. In addition, this author suggested that photosynthesis, apparently, is more directly related to growth in diameter than growth in height. In fact, the correlation between total biomass accumulation and stem diameter in T. aurea was high $(\mathrm{r}=0.94 ; \mathrm{p}<0.01)$, indicating that this parameter can be a good indicator of the acclimation of $T$. aurea plants to the environment.

Shading caused severe changes in gas exchange in T. aurea seedlings (Figure 5 and 6). T. aurea stomatal conductance ranged from 0.1 to $0.56 \mathrm{~mol} \mathrm{H}_{2} \mathrm{O}$ and from 0.08 to $0.38 \mathrm{~mol}$ $\mathrm{H}_{2} \mathrm{O}$ according to environmental conditions at 51 and 70 days after planting, respectively (Figure 5A and B). In 50\% shade, $T$. aurea seedlings seemed to have the best stomatal conductance at 70 days after planting (Figure 5B). More intense shade inhibited stomatal conductance, which may be due to the observed increase in leaf to air vapor pressure deficit $\Delta \mathrm{w}$ (Figure 1). In general, there was an increase in gs when seedlings were transferred into direct sunlight, and it declined again after three days of exposure to natural light conditions. Reductions in gs have also been observed in seedlings of T. chrysotricha (Endres
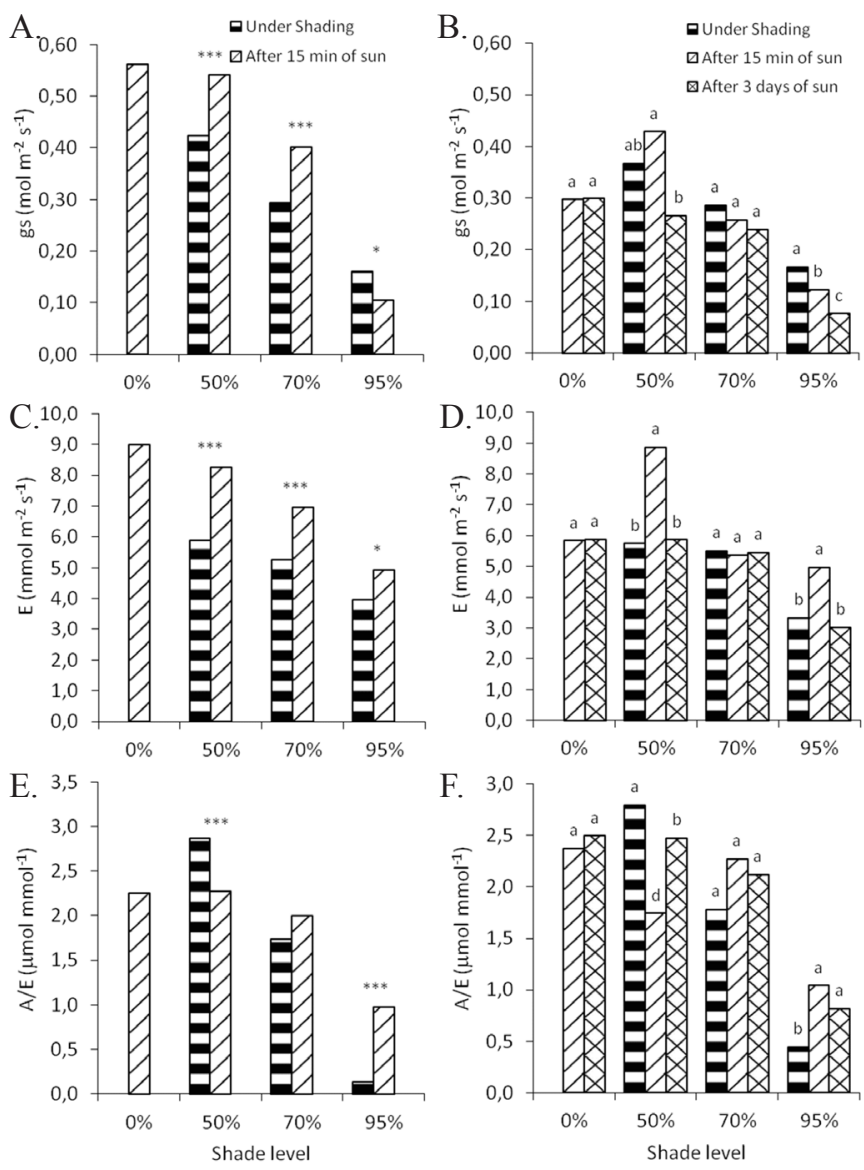

Columns in the same shading level are significantly different at $P<0.05\left(^{*}\right)$ and at $P<0.01$ $\left({ }^{* *}\right)$ by t-test $(N=8)$ and columns in the same shading level followed by different letters indicate significant differences $(N=8$, Tukey test, $\mathrm{P}<0.05)$

Figure 5. The leaf stomatal conductance $(A, B)$, transpiration $(C, D)$ and instantaneous water use efficiency (E, F) of the Tabebuia aurea grown under different shading levels and then the seedlings were transferred to full sunlight, measured 15 min later and then only measured again 3 days later. Figures $5 \mathrm{~A}, 5 \mathrm{C}$ and $5 \mathrm{E}$ measure 51 days of having been sown. Figures $5 \mathrm{~B}, 5 \mathrm{D}$ and $5 \mathrm{~F}$ measure 70 days of having been sown

et al., 2010), Paeonia suffruticosa (Zhang et al., 2003) and Cupania vernalis Camb. (Sapindaceae) (Lima Jr. et al., 2006) exposed to natural light conditions after periods of 130, 60 and 150 days, respectively, under shade. Stomatal conductance was strongly correlated with PAR $(r=0.80 ; p<0.01)$ under shade but was not correlated with PAR under full sunlight (Table 1).

T. aurea transpiration decreased with increasing shading, especially at 51 days after planting, with a recovery trend in the three shading levels after $15 \mathrm{~min}$ of exposure to sunlight (Figure 5C). Similar to the findings for stomatal conductance under $50 \%$ shade, T. aurea seedlings had maximal transpiration 70 days after planting (Figure 5D) after $15 \mathrm{~min}$ of exposure to sunlight (Figure 5D). However, after three days of exposure to sunlight, these values were reduced to values similar to those found for plants subjected to shading. Transpiration was correlated with PAR $(r=0.67 ; p<0.01)$ only under shade. A high correlation between transpiration and stomatal conductance was also observed of both under shade $(\mathrm{r}=0.91 ; \mathrm{p}<0.01)$ and under different light intensities $(r=0.82 ; \mathrm{r}=0.91 ; \mathrm{r}=0.98$; Table 1$)$, 

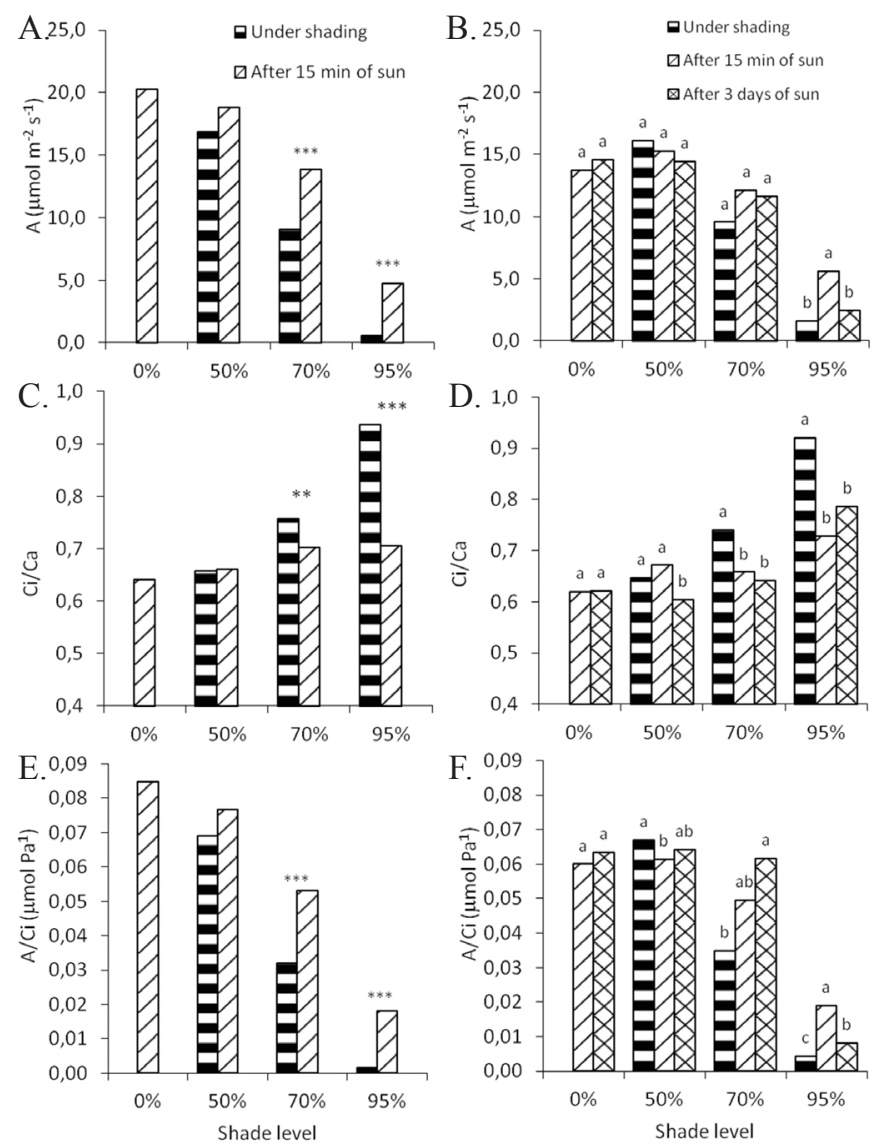

Columns in the same shading level are significantly different at $\left.\mathrm{P}<0.05{ }^{*}\right)$ and at $\mathrm{P}<0.01$ $\left({ }^{*}\right)$ by t-test $(\mathrm{N}=8)$ and columns in the same shading level followed by different letters indicate significant differences $(N=8$, Tukey test, $P<0.05)$

Figure 6. The leaf stomatal conductance $(\mathrm{A})$, transpiration (B), leaf internal and external $\mathrm{CO}_{2}$ concentration ratio (C), photosynthesis (D), instantaneous carboxylation efficiency $(E)$, instantaneous water use efficiency $(F)$ and leaf-to-leaf chamber temperature difference $(\mathrm{g})$ of the Tabebuia aurea grown under different shading levels and then the seedlings were transferred to full sunlight, measured 15 min later and then only measured again 3 days later

showing that with decreasing light availability, transpiration and conductance are highly interdependent.

Zhang et al. (2003) observed reductions in the transpiration of Paeonia suffruticosa subjected to 40 and 95\% shading. However, changes in the transpiration rate due to shading were not observed at 130 days after planting in T. chrysotricha grown under up to $95 \%$ shade (Endres et al., 2010) or at 150 days after planting in Cupania vernalis Camb. (Sapindaceae) grown under up to $70 \%$ shade (Lima Jr. et al., 2006). Thus, in environments with different lighting conditions, plants can show great plasticity in relation to different irradiance levels, altering some features of leaf anatomy. These alterations may be directly related to inherent characteristics of gas exchange, such as photosynthetic rate, stomatal conductance and transpiration, therefore favoring a better development of seedlings under different environmental conditions (Lima Jr. et al., 2006).

In $T$. aurea plants, liquid/net photosynthesis was strongly influenced by shade, which is reflected in the high ratio of PAR to photosynthesis in seedlings grown under shade $(r=0.93$;
Table 1, Figures. 6A and B). The transfer of seedlings into direct sunlight for $15 \mathrm{~min}$ increased photosynthesis in seedlings that had been grown under 70 and $95 \%$ shade at 51 days after planting and only in those that had been grown under $95 \%$ shade at 70 days after planting. At both times (51 and 70 days after planting), the stomatal conductance of seedlings grown under 95\% shade decreased and photosynthesis increased when the seedlings were exposed for $15 \mathrm{~min}$ to full sunlight. In addition, there was a reduction in internal and external leaf $\mathrm{CO}_{2}$ concentration ratio under these conditions (Figure $5 \mathrm{C}$ ), showing that stomatal conductance did not limit photosynthesis in conditions of intense shading.

Other authors have also found decreases in photosynthetic activity. Alvarenga et al. (2003) found that photosynthetic activity decreases as shading increased up to $70 \%$ in young plants of $C$. urucurana Baill. Similar results were found by Welander \& Ottosson (2000) in Quercus robur under the same light conditions, by $\mathrm{Mu}$ et al. (2010) in Triticum aestivum L. from $22 \%$ of the incident solar radiation, by Zhou et al. (2010) in Lycoris radiata var. radiata under $85 \%$ shade and by Endres et al. (2010) in T. chrysotricha seedlings, especially under 95\% shade. In Lindera melissifolia, however, the highest photosynthetic rates were observed when the plants were grown under $58 \%$ shade; yet, when irradiance was reduced by $81 \%$ (shading) net/liquid photosynthesis decreased significantly (Aleric \& Kirkman, 2005).

After three days of exposure to full sunlight, seedlings that had been grown under shade showed no increase in photosynthesis (Figure 6B). Moreover, the positive correlation between PAR and photosynthesis $(r=0.93)$ was negative in plants that had been grown under shade $(r=-0.46)$ after their transfer into full sunlight for three days, indicating possible damage to the photosynthetic apparatus.

Thus, T. aurea attempts to increase its photosynthetic efficiency under low light intensity (e.g., in 50\% shade), but when it is transferred into full sunlight, the combination of high PPFD and temperature may damage PSII in leaves of this species, as has been shown in L. radiata var. radiata (Zhou et al., 2010).

\section{Conclusions}

1. The shade level in a nursery should be chosen based not only on the maximum growth of seedlings in the nursery but also on the adaptation of the seedlings to transplanting at the reforestation site. Thus, T. aurea seems to have satisfactory growth under $50 \%$ shade in the nursery. This species also shows a great capacity for regulating biomass allocation, especially regarding its leaves, to survive even under extreme shading conditions ( $95 \%$ shade).

2. The transfer of seedlings to sunlight caused drastic physiological changes, especially in the leaves. Both stomatal conductance and photosynthesis were strongly dependent on PAR when the seedlings were shaded. Based on morphological and physiological characteristics, it can be concluded that T. aurea is a heliophytic species that should be grown in full sunlight or under up to $50 \%$ shade to maximize growth in the nursery and minimize stress when transferring seedlings to the final planting site. 


\section{ACKNOWLEDGEMENTS}

Thanks are due to FAPEAL (Fundação de Amparo a Pesquisa do Estado de Alagoas) and to $\mathrm{CNPq}$ (Conselho Nacional de Desenvolvimento Científico e Tecnológico) for financial assistance.

\section{Literature Cited}

Aguiar, F. F. A.; Kanashiro, S.; Tavares, A. R.; Pinto, M. M.; Stancato, G. C; Aguiar, J.; Nascimento, T. D. R. Germinação de sementes e formação de mudas de Caesalpinia echinata Lam. (pau-brasil): Efeito de sombreamento. Revista Árvore, v.29, p.871-875, 2005.

Aleric, K. M.; Kirkman, L. K. Growth and photosynthetic responses of the federally endangered shrub, Lindera melissifolia (Lauraceae), to varied light environments. American Journal of Botany, v.92, p.682-689, 2005.

Almeida, L. S.; Maia, N.; Ortega, A. R.; Angelo, A. C. Crescimento de mudas de Jacaranda puberula Cham. em viveiro submetidas a diferentes níveis de luminosidade. Ciência Florestal, v.15, p.323-329, 2005.

Alvarenga, A. A.; Castro, E. M.; Lima Jr., E. de C.; Magalhães, M. M. Effects of different light levels on the initial growth and photosynthesis of Croton urucurana Baill. in southeastern Brazil. Revista Árvore, v.27, p.5357, 2003.

Azevedo, I. M. G. de; Alencar, R. M. de; Barbosa, A. P.; Almeida, N. O. Estudo do crescimento e qualidade de mudas de marupá (Simarouba amara Aubl.) em viveiro. Acta Amazonica, v.40, p.157-164, 2010.

Benincasa, M. M. P. Análise de crescimento de plantas: Noções básicas. Jaboticabal: FUNEP, 2003. 41p.

Carvalho, N. O. S.; Pelacani, C. R.; Rodrigues, M. O. de S.; Crepaldi, I. C. Crescimento inicial de plantas de licuri (Syagrus coronata (Mart.) Becc.) em diferentes níveis de luminosidade. Revista Árvore, v.30, p.351-357, 2006.

Chazdon, R. Beyond deforestation: Restoring forests and ecosystem services on degra ded lands. Science, v.320, p.1458-1459, 2008.

Claussen, J. W. Acclimation abilities of three tropical rainforest seedlings to an increase in light intensity. Forest Ecology and Management, v.80, p.245-255, 1996.

Dantas, B. F.; Lopes, A. P.; Silva, F. F. S. da; Lúcio, A. A.; Batista, P. F.; Pires, M. M. M. da L.; Aragão, C. A. Taxas de crescimento de mudas de catingueira submetidas a diferentes substratos e sombreamentos. Revista Árvore, v.33, p.413-423, 2009.

Endres, L.; Câmara, C. A.; Ferreira, V. M.; Silva, J. V. Morphological and photosynthetic alterations in the Yellowipe, Tabebuia chrysotricha (Mart. Ex DC.) Standl., under nursery shading and gas exchange after being transferred to full sunlight. Agroforest System, v.78, p.287-298, 2010.

Felfili, J. M.; Hilgbert, L. F.; Franco, A. C.; Sousa Silva, J.C.; Rezende, A. L.; Nogueira, M. V. P. Comportamento de plântulas de Sclerolobium paniculatum Vog. var. rubiginosum (Tul.) Benth. sob diferentes níveis de sombreamento, em viveiro. Revista Brasileira de Botânica, v.22, p.297-301, 1999.
Fonseca, E. P.; Valéri, S. V.; Miglioranza, E.; Fonseca, N. A. N.; Couto, L. Padrão de qualidade de mudas de Trema micrantha (L.) Blume, produzidas sob diferentes períodos de sombreamento. Revista Árvore, v.26, p.515$523,2002$.

Gonçalves, J. F. C.; Barreto, D. C. S.; Santos, J. R. V. M.; Sampaio, P. T. B.; Buckeridge, M. S. Growth, photosynthesis and stress indicators in young rosewood plants (Aniba rosaeodora Ducke) under different light intensities. Brazilian Journal of Plant Physiology, v.17, p.325-334, 2005.

Gordon, J. C. Effect of shade on photosynthesis and dry weight distribution in yellow birch (Betula alleghaniensis Britton) seedlings. Ecology, v.50, p.924-926, 1969.

Kozlowski, T. T. Tree growth. New York: The Ronald Press. 1962. 325p.

Lima Jr., E. C.; Alvarenga, A. A.; Castro, E. M.; Vieira, C. V.; Barbosa, J. P. R. A. D. Aspectos fisioanatômicos de plantas jovens de Cupania vernalis Camb. submetidas a diferentes níveis de sombreamento. Revista Árvore, v.30, p.33-41, 2006.

Lima Jr., E. C.; Alvarenga, A. A.; Castro, E. M.; Vieira, C. V.; Oliveira, H. M. Trocas gasosas, características das folhas e crescimento de plantas jovens de Cupania vernalis Camb. submetidas a diferentes níveis de sombreamento. Ciência Rural, v.35, p.1092-1097, 2005.

Lorenzi, H. Árvores Brasileiras: manual de identificação e cultivo de plantas arbóreas do Brasil. São Paulo: Plantarum. 2002. 368p.

Mu, H.; Jiang, D.; Wollenweber. B.; Dai, T.; Jing, Q.; Cao, W. Long-term low radiation decreases leaf photosynthesis, photochemical efficiency and grain yield in winter wheat. Journal of Agronomy \& Crop Science, v.196, p.38-47, 2010.

Ortega, A. R.; Almeida, L. S.; Maia, N.; Angelo, A. C. Avaliação do crescimento de mudas de Psidium cattleianum Sabine a diferentes níveis de sombreamento em viveiro. Cerne, v.12, p.300-308, 2006.

Scalon, S. P. Q.; Mussury, R. R.; Rigoni, M. R.; Scalon Filho, H. Crescimento inicial de mudas de Bombacopsis glabra (Pasq.) sob condição de sombreamento. Revista Árvore, v.27, p.753-758, 2003.

Siddique, I.; Engel, V. L.; Parrotta, J. A.; Lamb, D.; Nardoto, G. B.; Ometto, J. P. H. B.; Martinelli, L. A.; Schmidt, S. Dominance of legume trees alters nutrient relations in mixed species forest restoration plantings within seven years. Biogeochemistry, v.88, p.89-101, 2008.

Silva, B. M. da S. E.; Lima, J. D.; Dantas, V. A. V.; Moraes, W. da S.; Sabonaro, D. Z. Efeito da luz no crescimento de mudas de Hymenaea parvifolia Huber. Revista Árvore, v.31, p.1019-1026, 2007.

Souza, B. D.; Rodrigues, B. M.; Endres, L.; Santos, M. G. Ecophysiology parameters of four Brazilian Atlantic Forest species under shade and drought stress. Acta Physiologiae Plantarum, v.32, p.729-737, 2010.

Vilela, A. E.; Ravetta, D. A. The effect of radiation on seedling growth and physiology in four species of Prosopis L. (Mimosaceae). Journal of Arid Environment, v.44, p.415$423,2000$. 
Welander, N. T.; Ottosson, B. The influence of low light, drought and fertilization on transpiration and growth in young seedllings of Quercus robur L. Forest Ecology and Management, v.127, p.139-151, 2000.

Wuethrich, B. Reconstructing Brazil's Atlantic Rainforest. Science, v.315, p.1070-1072, 2007.
Zhang, S.; Ma, K.; Chen, L. Response of photosynthetic plasticity of Paeonia suffruticosa to changed light environments. Environmetal and Experimental Botany, v.49, p.121-133, 2003.

Zhou, S. B.; Liu, K.; Zhang, D.; Li, Q. F.; Zhu, G. P. Photosynthetic performance of Lycoris radiata var. radiata to shade treatments. Photosynthetica, v.48, p.241-248, 2010. 